\title{
The design and validation of an instrument to measure teachers' professional development at work
}

Citation for published version (APA):

Evers, A., Kreijns, K., \& Van der Heijden, B. (2016). The design and validation of an instrument to measure teachers' professional development at work. Studies in Continuing Education, 38(2), 162-178.

https://doi.org/10.1080/0158037X.2015.1055465

\section{DOI:}

10.1080/0158037X.2015.1055465

Document status and date:

Published: 01/01/2016

Document Version:

Peer reviewed version

\section{Document license:}

CC BY-NC-ND

Please check the document version of this publication:

- A submitted manuscript is the version of the article upon submission and before peer-review. There can be important differences between the submitted version and the official published version of record. People interested in the research are advised to contact the author for the final version of the publication, or visit the DOI to the publisher's website.

- The final author version and the galley proof are versions of the publication after peer review.

- The final published version features the final layout of the paper including the volume, issue and page numbers.

Link to publication

\section{General rights}

Copyright and moral rights for the publications made accessible in the public portal are retained by the authors and/or other copyright owners and it is a condition of accessing publications that users recognise and abide by the legal requirements associated with these rights.

- Users may download and print one copy of any publication from the public portal for the purpose of private study or research.

- You may not further distribute the material or use it for any profit-making activity or commercial gain

- You may freely distribute the URL identifying the publication in the public portal.

If the publication is distributed under the terms of Article 25fa of the Dutch Copyright Act, indicated by the "Taverne" license above, please follow below link for the End User Agreement:

https://www.ou.nl/taverne-agreement

Take down policy

If you believe that this document breaches copyright please contact us at:

pure-support@ou.nl

providing details and we will investigate your claim.

Downloaded from https://research.ou.nl/ on date: 26 Apr. 2023 
Title: The Design and Validation of an Instrument to Measure Teachers' Professional Development at Work ${ }^{1}$

\section{Arnoud T. Evers, Karel Kreijns}

Open University of the Netherlands, Welten Institute, Research Centre for Learning, Teaching and Technology

E-mail address:

arnoud.evers@ou.nl

karel.kreijns@ou.nl

\section{Béatrice I. J. M. van der Heijden}

Radboud University, Institute for Management Research, Nijmegen, the Netherlands

Open University of the Netherlands

E-mail address: B.vanderHeijden@fm.ru.nl

Future correspondence (corresponding author):

Arnoud T. Evers

Open University of the Netherlands

Valkenburgerweg 177

6401 DL Heerlen

Telephone number: +31-(0)45-5762925

Fax number: +31-(0)45-5762782

E-mail address: arnoud.evers@ou.nl

\footnotetext{
${ }^{1}$ See for the article as published online: DOI: https://doi.org/10.1080/0158037X.2015.1055465. Please refer to this article as: Evers, A. T., Kreijns, K., \& Van der Heijden, B. I. J. M. (2016). The design and validation of an instrument to measure Teachers' Professional Development at Work. Studies in Continuing Education 38(2), 162-178.
} 


\begin{abstract}
After graduation it is essential for teachers to continue working on their professional development since they need to be prepared for the requirements of tomorrow's knowledge- and technology-based society, a more varied student and pupil population creating new responsibilities, and higher social expectations from schools and the society as a whole. Although attention for teachers' professional development at work is increasing, the availability of valid survey instruments that measure their participation in professional development at work is still limited. Based on a literature review, such an instrument was designed. This 21 -item selfreport measure, using a 4-point rating scale, makes an inventory of teachers' participation in activities contributing to professional development. The purpose of the instrument is to make teachers, school leaders and other stakeholders aware of whether, and to what degree, teachers engage in learning at work. This is important because ultimately the quality of education depends on it. A survey was administered in 9 Dutch primary schools and 15 Dutch secondary schools. Exploratory and Confirmatory Factor Analysis confirmed a six-factor structure, and augments earlier findings in the field. The reliabilities of the six subscales were sufficient to good.
\end{abstract}

Keywords: Teachers; Professional Development at Work; TPD@Work; Confirmatory Factor Analysis; Measurement Instrument 


\section{Introduction}

Initial teacher education is the first step in becoming a teacher. After graduation, teachers need to continue working on their professional development as the demands in our knowledge society keep increasing for both students and their teachers (Brandsford et al. 2005). Students need to possess twenty-first century skills that are needed to cope with the requirements of tomorrow's knowledge- and technology-based society (Voogt and Roblin 2012). In turn, teachers must be qualified to educate those students in order to make sure that they will use these skills in their future working life. At the same time, teachers need to be prepared for a more varied student and pupil population in their classroom thereby creating new responsibilities, as well as be prepared for higher social expectations of schools in general (OECD 2005). This underlines the need for professional development of teachers, defined in this article as: 'The process by which teachers acquire the knowledge, skills and values which will improve the service they provide to clients' (Hoyle and John 1995 17). Professional development is understood in terms of the type of (professional) learning, while (professional) learning is considered as the actual learning process, or learning activities. The actual learning process may take place in formal, non-formal or informal settings (Eraut 2000) found at or through work.

In the current article, we focus on teachers' continuing professional development at (or through) work as the significance and value of this type of professional development is increasingly demonstrated (Billett, Harteis, and Eteläpelto 2008; Eraut 2004; Malloch et al. 2011; Tynjälä 2013). Specifically, Park and Jacobs (2011) found that investment in learning at the workplace positively influences organisational-level outcomes (i.e. job competence, labour productivity, and enthusiasm). In addition, Jurasaite-Harbison and Rex (2010) stated that teacher informal learning at the workplace is important for teachers' professional growth and career-long development. According to Postholm (2012), learning in school is the best ap- 


\section{MEASURING TEACHERS' PROFESSIONAL DEVELOPMENT AT WORK}

proach for further development of teachers. More precisely, teachers need innovative ways of continuing school-based professional development if they want to change the ways in which they perform their work. As such, they not only meet the demand for teacher learning but also make the best use of the limited funds available (Livingston 2012). Therefore, it seems worthwhile to expand our empirical knowledge on teachers' professional development at work.

It is important to develop an instrument which can be used by teachers, school leaders and policy makers to make an inventory about the degree to which teachers participate in professional development at work. By using such an instrument professional development activities become visible for these actors and, if necessary, appropriate actions can be taken. For example, participation in professional development activities at work which teachers score low on can be paid attention to. This will then contribute to the quality of education in schools. The ultimate goal of teacher professional learning is progress in pupil learning. School-based professional development narrows the gap between teacher professional learning and the goal of pupil learning (Livingston 2012).

Kwakman (2003) is credited to be one of first authors who developed a survey instrument to measure teachers' professional development at work. Certain categories of professional development that she investigated (such as like reading, experimenting, reflecting and collaborating) still seem to dominate the literature (e.g. Benson 2010; Blokhuis 2006; Bound 2011; Czerniawski 2013; Eraut 2007; Geijsel et al. 2009; Goh 2013; Grangeat and Gray 2007; OECD 2009; Tynjälä 2008), as will be elaborated in the next section. However, an empirically validated instrument that captures all of these categories simultaneously is currently not available. Kwakman (2003) could not empirically confirm her proposed categorization, and since then no progress has been made in operationalising this complex construct. To remedy this we have developed a survey on teachers' professional development at work (which we 


\section{MEASURING TEACHERS' PROFESSIONAL DEVELOPMENT AT WORK}

will refer to as TPD@Work), comprising the most significant categories of professional development activities at work.

This article starts with a literature review on professional development at work, in which five dominant categories of professional development activities are described. Then, we will present the new TPD@Work survey, followed by the data collection procedure and the sampling of primary and secondary school teachers. We have tested the validity of the instrument using an Exploratory (EFA) and Confirmatory Factor Analysis (CFA) of which the results will be clarified. This article closes with a discussion and conclusions.

\section{Literature on Teachers' Professional Development at Work}

Based on an elaborate literature review, Kwakman (2003) distinguished four main theoretical categories of professional development activities at work: 1) Reading, 2) Experimenting, 3) Reflecting, and 4) Collaborating. Her theoretical categories of professional development activities at work emerged in various recent international studies (Avalos 2011; Benson 2010; Eraut 2007; Geijsel et al. 2009; Grangeat and Gray 2007; Hoekstra et al. 2009; Runhaar 2008; Tynjälä 2008). However, Kwakman (2003) could not empirically confirm these categories. Because her review was conducted more than a decennium ago, and the ways of professional development change quickly, we have extended her review including findings from recent literature. As a result, five theoretical categories were considered relevant: 1) Keeping up-todate, 2) Experimenting, 3) Reflecting and asking for feedback, 4) Collaborating with colleagues with the aim of improving lessons, and 5) Collaborating with colleagues with the aim of improving school development. We will now discuss each of these theoretical categories and the underlying recent literature. Moreover, we will also consider the role of ICT (Information and Communication Technologies).

Both reading and participation in training related to work are explicit strategies in keeping up-to-date about ongoing educational developments. The goal of reading is acquiring new 


\section{MEASURING TEACHERS' PROFESSIONAL DEVELOPMENT AT WORK}

knowledge and insights. Teachers, for example, keep up-to-date by studying subject matter literature, reading educational literature (Geijsel et al. 2009; Kwakman 2003), and nowadays visiting educational sites on the internet. Formal on-the-job and off-the-job training activities are a part of learning at work (Cheetham and Chivers 2001; Park and Jacobs 2011; Tynjälä 2008) and a way to acquire new skills and keep up-to-date (Geijsel et al. 2009). Short formal training courses can be a stimulus for further teachers' professional development at work (Grip 2008), although the current value of training for teachers is considered to be limited (Bubb and Earley 2013). Earlier research has indicated that general training and development activities did not have an influence on a crucial learning outcome: occupational expertise (Evers et al. 2011). Studies suggested that to make training effective, care should be taken that the content of training is not too general but that it has a strong connection to the daily work activities of teachers. As Postholm (2012) pointed out, in training courses a focus on practiceoriented exploratory work appears to be beneficial for teachers' development.

With regard to our second category of professional development activities, Kwakman (2003) characterised experimenting as an intentional effort of teachers to undertake something new within the classroom. Several authors have studied experimenting by teachers. Benson (2010), for example, reported about a collective case study of Hong Kong secondary school teachers. Benson concluded that the impact of teacher education courses depended on experimentation with new ideas in the classroom. Geijsel et al. (2009) classified experimentation as an important professional learning activity and proved several positive predictors: collaboration among teachers, internalisation of school goals into personal goals, and self-efficacy. Apart from mapping the impact of experimenting and its predictors, previous literature was inconclusive about the issue whether experimenting and reflecting, as learning activities, can be distinguished as separate categories. For example, the empirical results from Geijsel et al. (2009) could not distinguish between experimentation and reflective practice. They concluded 


\section{MEASURING TEACHERS' PROFESSIONAL DEVELOPMENT AT WORK}

that teachers seem to view reflective practice as an integral part of experimentation. Opposing this view, Hoekstra et al. (2009) — in line with Kwakman — grouped experimenting and reflecting (both theoretically and empirically) as separate categories of teachers' professional development at work activities. In agreement with both Hoekstra et al. (2009) and Kwakman (2003), we also perceive experimenting and reflecting as separate, although strongly related, categories.

Third, many authors wrote and conducted research about reflecting and asking for feedback; as a learning activity, it even stands out in the number of articles written about this topic in the last decade (Avalos 2011). In many professional development programmes, reflecting has become a key strategy (Marcos, Sanchez, and Tillema 2011) and is seen as the keystone of professional development (Schön 1983). Reflection implies stepping back from an experience to consider the meaning to oneself through the analysis and consequences of that experience that lead to tentative theories and solutions, which in the end are tested in the actual workplace (Daudelin 1996; Retallick 1999). These steps lead to the transformation of beliefs, values and practices (Opfer, Pedder, and Lavicza 2011). Eraut (2007) found that reflection within work or learning processes at work often occurred while listening to or observing others. His findings confirmed the key role of critical reflection for learning and change. Runhaar's (2008) studies showed that reflection by teachers played a decisive role in learning from practice. Asking for feedback may both be an immediate starting-point for reflection and be an outcome of a reflection process, and as such the two are highly intertwined (Prilla, Degeling, and Herrmann 2012; Ramani and Krackov 2012). Feedback is critical to individuals' learning and performance improvement in the context of their work (see also Mulder and Ellinger 2013). In line with Kwakman's (2003) reasoning, we therefore perceive asking feedback as an essential element of reflecting. Borko (2004) pointed out that teacher learning should have a dual focus: an individual perspective (in this article: keeping up-to-date, exper- 


\section{MEASURING TEACHERS' PROFESSIONAL DEVELOPMENT AT WORK}

imenting, reflecting and asking for feedback) and a group-level perspective, wherein collaborative interactions occur when groups of teachers work together to investigate and advance their practice. This dual process has also recently been pointed out as a major issue in teachers' workplace learning (Avalos 2011).

Therefore, finally, collaboration is important as it provides the necessary support for learning, affords teachers critical thinking, and brings new challenges and ideas (Kwakman 2003). Some authors viewed collaboration as a predictor of (informal) learning (Geijsel et al. 2009; Hoekstra et al. 2009). Others saw learning as a process that takes place while collaborating. In this second view social interaction is at the base of learning (Vygotsky 1978). For example, Tynjälä (2008) found that people learned at work by collaborating with colleagues. Interactions with colleagues are seen as an important source for gaining professional knowledge (Grangeat and Gray 2007) and further development of teachers (Park et al. 2007). From previous work, Little (1990) already concluded that the specific content (i.e. what is learned) of collegial interaction determined its contribution and added value in the light of professional development. For this reason we have distinguished between two categories of collaborating with colleagues that centre on the content: (1) 'collaborating with colleagues with the aim of improving lessons' and (2) 'collaborating with colleagues with the aim of improving school development' (see also Kwakman 2003).

To conclude, the above literature review led us to the following five theoretical categories: (1) Keeping up-to-date, (2) Experimenting, (3) Reflecting and asking for feedback, (4) Collaborating with colleagues with the aim of improving lessons, and (5) Collaborating with colleagues with the aim of improving school development. Since Kwakman's (2003) research that took place more than 10 years ago, the role of ICT in schools has increased substantially (Kozma 2003) and is necessary in the light of the educational demands of the knowledge society (Dede 2000; Ward 2005). Therefore, in line with the studies of Dede (2000), Law, 


\section{MEASURING TEACHERS' PROFESSIONAL DEVELOPMENT AT WORK}

Pelgrum, and Plomp (2008), Pelgrum and Voogt (2009), and Ward (2005), in each of our five categories of professional development activities the use of ICT is important. Over the years, the use of ICT moved beyond presentation-centred forms of education and focused on the integration and application of ICT in teachers' educational practices (Dede 2000; Ward 2005) as well as on new ways of teaching and learning by means of the use of ICT (Pelgrum and Voogt 2009).

\section{Method}

\section{Designing the TPD@Work Survey}

Kwakman's work was a central source for our TPD@Work survey. Table 1 shows all the items that were included in her factorial analyses; these items formed the original list. Our survey was based on this original list. Kwakman removed three learning activities (these are the bold items in Table 1) as they had low factor loadings in her empirical work, however, in our opinion these are appreciable learning activities in nowadays' education, and therefore were included in our analyses.

$* * * * * * * * * * * * * * * * * * * * *$

Insert Table 1 about here

$* * * * * * * * * * * * * * * * * * * * *$

In developing items aimed to measure participation in professional learning activities, we first retained the five theoretical categories as discussed earlier in this article in mind: 1) Keeping up-to-date, 2) Experimenting, 3) Reflecting and asking for feedback, 4) Collaborating with colleagues with the aim of improving lessons, and 5) Collaborating with colleagues with the aim of improving school development. In other words, the literature was leading in developing the items and building the categories. Consequently, it was needed to rephrase and unite some of the items of Kwakman's original list. To accomplish this we also made use of a more recent study by Kuiper-Rinsema (2007) who replicated the study of Kwakman. Some other 


\section{MEASURING TEACHERS' PROFESSIONAL DEVELOPMENT AT WORK}

items were also deleted as these were considered not to fit in the theoretical categories we have defined (see Appendix 1).

Second, we strived for each theoretical category to be represented by a sufficient amount of items. The items that corresponded with the learning activities and that emerged from the interviews that Kwakman held with teachers were not equally distributed among her four theoretical categories. As a result, certain categories were composed of only a few items. The fact that Kwakman could not find her theoretical categories represented in the empirical outcomes from the factor analyses could perhaps be due to this imbalance in distribution. Third, in each theoretical category, one ICT-related item was developed based on the guidelines as discussed at the end of the 'literature on teachers' professional development at work' section that has been outlined above. Thus, ICT usage was embedded within the activity as a means to an end. In the TPD@Work survey, it was made clear to the respondents that ICT should be interpreted broadly and that it included computers and internet as well.

Fourth, following Kwakman (2003) regarding the measurement of how often teachers participated in each learning activity, we used a self-report 4-point rating scale: $1=$ hardly ever, 2 = sometimes, 3 = fairly often, and $4=$ often. This can be seen as an adequate rating scale to measure the frequency of behaviour (Michels and Voeten 1993).

The development of the survey items was performed by three researchers on the basis of these four guidelines. The resulting survey was pilot tested with several experts in the field of primary and secondary education (both teachers and directors). The experts were asked whether the items in the survey were clearly formulated and whether there were omissions or other points for discussion (in the light of the face validity of the operationalization). No omissions in terms of content of the survey were reported. Furthermore, the survey was wellreceived and seen as useful (some comments of the experts that illustrated this were: 'Formulations are clear', 'The questions are clear, I don't need to read back', and 'Learning activities 


\section{MEASURING TEACHERS' PROFESSIONAL DEVELOPMENT AT WORK}

are not all unique, but good questions'). See Table 2 for the full outline of the items in the survey.

$* * * * * * * * * * * * * * * * * * * * *$

Insert Table 2 about here

$* * * * * * * * * * * * * * * * * * * * *$

\section{Data Collection and Sample}

Data was collected by means of a survey study that was administered in 9 Dutch primary schools and 15 Dutch secondary schools. As a result, our sample consisted of teachers working in primary and secondary education. The survey was web-based, except for one school, where a paper-and-pencil form was used. We approached 2385 teachers (we have sent two reminders to each school) of whom in total 692 (118 primary teachers and 574 secondary teachers) returned a completely filled out survey. This implied a total response rate of $29 \%$.

The sample characteristics in percentages (gender, educational level, and age) are shown in Table 3. In general, the representativeness of our sample, in terms of gender, educational level, and age for the Dutch population of secondary and primary teachers appeared to be sufficient (see Education 2013; Vogels and Bronneman-Helmers 2006).

$* * * * * * * * * * * * * * * * * * * * *$

Insert Table 3 about here

$* * * * * * * * * * * * * * * * * * * * *$

\section{Data Analysis and Results}

Data was analysed using IBM SPSS 18.0 and AMOS 18.0. We randomly divided the data set into two equal sub sets of respondents: $n=346$. Using the first sub set, we performed an EFA. We have chosen this EFA technique because we adjusted the original categories of Kwakman (2003) and added some additional, new items as well. According to Hurley et al. (1997) and Kelloway (1995), an exploratory technique is regarded as more suitable than a confirmatory 


\section{MEASURING TEACHERS' PROFESSIONAL DEVELOPMENT AT WORK}

technique in the first phase of scale development. Because of the adjustments and additions, EFA is therefore justified. Using the second sub set, CFA with AMOS was performed. The CFA aimed to confirm the factor structure found in the first sub set of data. In the next sections, more details about the factor analytic approaches are provided.

\section{Results of Exploratory Factor Analysis on Sub set 1}

We performed a principal component EFA with oblique rotation (direct Oblimin, $\delta=0$ ) for the first sub set on the 25 items (see Table 2). Factors with eigenvalues $>1$ were retained (Kaiser 1960). The Kaiser Meyer Olkin measure to test the sampling adequacy appeared to be sufficient (.85). Bartlett's test of sphericity $\left(\chi^{2}(300)=2820.22, p<0.001\right)$ proved that correlations between items were large enough for conducting a principal components analysis.

In total, four items were removed after the initial factor analysis and this resulted in the final six factors as shown in the pattern matrix in Table 4. The item 'Reflecting on the different educational applications of ICT' was deleted because it significantly loaded, as opposed to our expectation, on the first factor in Table 4. The item 'Using peer coaching in case my colleagues and I experience teaching problems' was deleted because it significantly loaded, unexpectedly, on the fourth factor in Table 4. Finally, we deleted the following two items, because, as opposed to our expectation, they fell outside any of the predefined theoretical categories: 'Discussing lessons with colleagues in an Electronic Learning Environment (ELO)' and 'Discussing school organisational matters with colleagues in an Electronic Learning Environment (ELO)'.

The six different factors (or dimensions) that were found in the final analysis generally confirmed the differentiation between the categories of professional development activities that were based on earlier literature in the field. Only the category 'Keeping up-to-date' appeared to consist of two factors which we labelled 'Keeping up-to-date: reading' and 'Keeping up-to-date: participation in training related to work'. The eigenvalues are shown in the last 


\section{MEASURING TEACHERS' PROFESSIONAL DEVELOPMENT AT WORK}

row of Table 4. A factor loading of .40 or larger was used to identify the primary factors on which the items loaded (Stevens 1992). The six factors appeared to explain, in total, $61.47 \%$ of the variance.

$* * * * * * * * * * * * * * * * * * * * *$

Insert Table 4 about here

$* * * * * * * * * * * * * * * * * * * * *$

\section{Reliabilities of the Subscales}

In order to measure the internal consistency of the six subscales (or factors), we used Cronbach's $\alpha$ for the entire data set (see Table 5). The internal consistency of all subscales was sufficient to good (> 0.7), except the 'Reflecting and asking for feedback' and 'Collaborating with colleagues with the aim of improving lessons' subscales which yielded internal consistencies slightly below 0.7 indicating somewhat weaker internal reliabilities.

$* * * * * * * * * * * * * * * * * * * * *$

Insert Table 5 about here

$* * * * * * * * * * * * * * * * * * * * *$

\section{Results of Confirmatory Factor Analysis on Sub set 2}

We executed a CFA using the second sub set $(n=346)$ to cross-validate and confirm the sixfactor structure derived in the analysis using the first sub set. First of all, we used the weighted least squares $\chi^{2}$ (chi-square/df) to assess the degree of fit between the model and the sub set 2 data. Additionally, the goodness-of-fit index (GFI) and the root mean square error of approximation (RMSEA) were used to evaluate the model fit. Models with GFI > .90 and RMSEA $<.08$ indicate an adequate fit between the model and the data (Browne and Cudeck 1993). Since these indices are dependent on sample size, it is recommended to inspect the non-normed fit index (NNFI), the incremental fit index (IFI), and the Bentler comparative fit index (CFI) as well (Marsh, Balla, and Hau 1996). These indices should be 90 or higher 
(Hoyle 1995). According to these fit indices, our data appeared to fit the six-factor model reasonably well: weighted least squares $\chi^{2}(174)=2.147, p<.001 ; \mathrm{GFI}=.906 ;$ RMSEA $=.058$; $\mathrm{NNFI}=.881 ; \mathrm{IFI}=.903 ; \mathrm{CFI}=.902$. As can be seen, only the NNFI was slightly below .90 . The estimated factor inter-correlations, factor loadings (above the arrows pointing to the left), and error variances (in the circles on the left) are displayed in Figure 1. All the items showed satisfactory factor loadings above .40 (Stevens 1992). The results also showed that reflecting and asking for feedback and experimenting could empirically be distinguished as two separate categories of teachers' professional development at work, although the correlation between these two categories was high $(r=.64, p<.01)$.

$* * * * * * * * * * * * * * * * * * * * *$

Insert Figure 1 about here

$* * * * * * * * * * * * * * * * * * * * *$ 


\section{Discussion and Conclusions}

Our goal in this article was to develop an instrument for measuring teachers' participation in professional development at work, which we have designated as the TPD@Work survey. We believe that, until now, a valid operationalization of teachers' professional development at work has not yet been developed. The research of Kwakman (2003) was significant in developing our instrument because of the fundamental theoretical categories she has discerned in her work as well as the interviews she has conducted with teachers about learning activities at work.

We confirmed the derived dominant theoretical categories with Exploratory and Confirmatory Factor Analyses. Contrasting Kwakman (2003), the categories that were found in our empirical approach appeared to be consistent with the categories in the literature which are still dominant and persistent in nowadays international literature (Avalos 2011; Benson 2010; Eraut 2007; Geijsel et al. 2009; Grangeat and Gray 2007; Tynjälä 2008): 1) Keeping up-to-date, 2) Experimenting, 3) Reflecting and asking for feedback, 4) Collaborating with colleagues with the aim of improving lessons, and 5) Collaborating with colleagues with the aim of improving school development. However, only one category 'Keeping up-to-date' appeared to consist of two sub categories: 'Training related to work' and 'Reading'. Although these learning activities share the common goal of keeping up-to-date, they cannot be perceived as one professional development at work category. We had to delete two items that had to do with participation in the ELO, because these did not match the original theoretical categories. A reason could be that the potential of the ELO was not fully exploited by teachers who might use it as a mere storage for learning materials or for making announcements. Indeed, the means of these learning activities were relatively low (item $17, \mathrm{M}=1.45 ; \mathrm{SD}=.74$; item $22, \mathrm{M}=1.51 ; \mathrm{SD}=.76$ ). Additionally, two items were deleted because each loaded on a different factor than expected. The item 'Reflecting on the different educational applications 


\section{MEASURING TEACHERS' PROFESSIONAL DEVELOPMENT AT WORK}

of ICT' appeared to significantly load on the factor 'experimenting', instead of 'reflecting'. Apparently, the experimental nature of educational applications of ICT for teachers is quite strong. The item 'Using peer coaching in case my colleagues and I experience teaching problems' significantly loaded on the factor 'reflecting and asking for feedback', instead of 'collaborating with colleagues with the aim of improving the lesson'. This could mean that reflecting and asking for feedback is a dominant aspect of peer coaching if teachers experience teaching problems. The final list of learning activities is depicted in Table 4.

Previous research was inconclusive about the question whether one could distinguish between 'experimenting' and 'reflecting and asking for feedback' as separate professional development at work categories (Geijsel et al. 2009; Hoekstra et al. 2009; Kwakman 2003). The results of our research showed that in our sample these categories can be empirically distinguished, although the correlation between the two was high. This could indicate that these two types of professional development activities at work are highly related. Indeed, all the distinguished categories are not fully mutually exclusive; they represent correlated aspects of participation in teachers' professional development at work. This is why the representation, that is, the factor structure, is oblique rather than orthogonal. There was overlap in the meaning of the scales, given the relatively high inter-scale correlations, but the distinctive power of the different scales was satisfactory, given the higher intra-scale correlations and the quantitative validation studies, regarding the convergent and discriminant validity.

An extension of the previous work is that our TPD@ Work survey included participation in training activities related to work because these are important learning activities comprising teachers' professional development at work (Cheetham and Chivers 2001; Tynjälä 2008). We also divided the category 'collaborating' in 'collaborating with colleagues with the aim of improving lessons' and 'collaborating with colleagues with the aim of improving school development'. This was because interactions with colleagues are an important source of gaining 


\section{MEASURING TEACHERS' PROFESSIONAL DEVELOPMENT AT WORK}

professional knowledge (Grangeat and Gray 2007; Tynjälä 2008), and in collegial interaction it is important that there is a goal and content connected to it (Little 1990). Finally, we included ICT professional development activities. Teachers' integration of ICT in their educational practices is one of the important changes since the beginning of the last decade.

\section{Limitations and Future Research}

A limitation of this study was its cross-sectional character. Future research using repeated measures is necessary in order to enable assessments of test-retest reliability. Moreover, a longitudinal inquiry is interesting because occupational performance improvement is a developmental process. More specifically, the increasing diversity in intra-individual change trajectories across time asks for innovative (lifespan) developmental perspectives, and attention for long-term effects (Schalk et al. 2011).

Although the theoretical categories were based on international literature, it would be interesting to cross-validate the factorial structure in other countries and to conduct crosscultural research. Moreover, future studies could explore the validity of this instrument for other teachers, for example for teachers working in a University setting. Whilst face validity (based on teachers and directors in the field of primary and secondary education) showed that this instrument is suitable for primary and secondary school teachers, future empirical research should establish whether the factor structure for primary and secondary school teachers is also the same. When using this instrument it is crucial to guarantee teachers' anonymity, which was also guaranteed in our research, to limit bias in self-reports.

Finally, we would like to stress that our instrument should not be seen as a 'ready-made' instrument, which can be used for the next decennia, but as a sound basis for work in progress. In a fast and ever-changing world, probably different TPD@Work activities will be important in the future (think, for instance, about different ELOs and social media). Therefore, it is crucial to keep our TPD@Work instrument up-to-date in the future. 


\section{MEASURING TEACHERS' PROFESSIONAL DEVELOPMENT AT WORK}

\section{Implications for Practice}

The TPD@Work survey can help teachers become aware of essential professional development activities at work. In the eyes of teachers, professional development is often equated to participation in training activities.

Another practical value of the instrument is that it allows teachers and school leaders to make an inventory as to what degree teachers participate in particular professional development activities at work. As professional development at work is often felt to be intangible, this instrument makes participation in teachers' professional development at work 'visible' for the school. Based on these results, school leaders can take specific actions on those professional development activities that score relatively low. Possible actions include making literature more accessible to teachers, stimulating reflection by encouraging teachers to attend each other's lesson, facilitating teachers to try out new teaching methods in class and encouraging collaboration among teachers. To facilitate change, teachers can also reflect together with colleagues in a team on their own scores of the TPD@Work survey, and on the total scores for their team and the school as a whole. They should focus on the question which learning activities at work need stimulation. This will contribute to teachers' quality and education in schools, because professional development at work brings the action (teacher professional learning) and the goal (pupil learning) closer together (Livingston 2012). 


\section{References}

Avalos, Beatrice. 2011. "Teacher Professional Development in Teaching and Teacher Education over Ten Years.” Teaching and Teacher Education 27 (1): 10-20. doi:10.1016/j.tate.2010.08.007.

Benson, Phil. 2010. “Teacher Education and Teacher Autonomy: Creating Spaces for Experimentation in Secondary School English Language Teaching.” Language Teaching Research 14 (3): 259-275. doi:10.1177/1362168810365236.

Billett, Stephen, Christian Harteis, and Anneli Eteläpelto, ed. 2008. Emerging perspectives of workplace learning. Rotterdam: Sense.

Blokhuis, F.T.L. 2006. “Evidence-Based Design of Workplace Learning.” Doctoral dissertation, Twente, University of Twente.

Borko, H. 2004. "Professional Development and Teacher Learning: Mapping the Terrain.” Educational Researcher 33 (8): 3-15.

Bound, H. 2011. "Vocational education and training teacher professional development: tensions and context." Studies in Continuing Education 33 (2): 107-119.

Brandsford, J., S. Derry, D. Berliner, and K. Hammerness. 2005. "Theories of Learning and Their Role in Teaching." In Preparing Teachers for a Changing World, ed. L. DarlingHammond, and J. Bransford, 40-87. San Fransisco, CA: Jossey-Bass.

Browne, M.W., and R. Cudeck. 1993. “Alternative Ways of Assessing Model Fit.” In Testing Structural Equation Models, ed. K.A. Bollen, and J. S. Long, 136-162. Beverly Hills, CA: Sage.

Bubb, S., and P. Earley. 2013. "The use of training days: finding time for teachers' professional development." Educational Research 55 (3): 236-248. doi: dx.doi.org/10.1080/00131881.2013.825161. 


\section{MEASURING TEACHERS' PROFESSIONAL DEVELOPMENT AT WORK}

Cheetham, Graham, and Geoff Chivers. 2001. "How Professionals Learn in Practice: An Investigation of Informal Learning amongst People Working in Professions." Journal of European Industrial Training 25 (5): 248-292.

Czerniawski, Gerry. 2013. 'Professional Development for Professional Learners: Teachers' Experiences in Norway, Germany and England.” Journal of Education for Teaching 39 (4): 383-399. doi:10.1080/02607476.2013.769339.

Daudelin, M. Wood. 1996. "Learning from Experience through Reflection.” Organizational Dynamics 24 (3): 36-48.

Dede, Chris. 2000. "Emerging Influences of Information Technology on School Curriculum." Journal of Curriculum Studies 32: 281-303. doi/abs/10.1080/002202700182763.

Education, Statistics labour market sectors of. 2013. "STAMOS.” Accessed July 202014. http://www.stamos.nl/index.bms?verb=showitem\&item=2.1.11.

Eraut, M. 2000. "Non-formal learning, implicit learning and tacit knowledge in professional work.” In The Necessity of Informal Learning, ed. F. Coffield, 12-31. Bristol: The Policy Press.

Eraut, Michael. 2004. "Informal learning in the workplace." Studies in Continuing Education 26 (2): $247-273$.

Eraut, Michael. 2007. "Learning from Other People in the Workplace." Oxford Review of Education 33 (4): 403-422. doi:10.1080/03054980701425706.

Evers, Arnoud T., Béatrice I.J.M. Van der Heijden, Karel Kreijns, and John T.G. Gerrichhauzen. 2011. “Organisational Factors and Teachers' Professional Development in Dutch Secondary Schools.” Journal of European Industrial Training 35 (1): 24-44. doi:10.1108/03090591111095727.

Geijsel, F.P., P.J.C. Sleegers, R.D. Stoel, and M.L. Krüger. 2009. “The Effect of Teacher Psychological and School Organizational and Leadership Factors on Teachers' 


\section{MEASURING TEACHERS' PROFESSIONAL DEVELOPMENT AT WORK}

Professional Learning in Dutch Schools." The Elementary School Journal 109 (4): 406427.

Goh, A.Y.S. 2013. "The significance of social relationships in learning to become a vocational and technical education teacher: a case study of three individuals." Studies in Continuing Education 35 (3): 366-378.

Grangeat, Michel, and Peter Gray. 2007. “Factors Influencing Teachers’ Professional Competence Development.” Journal of Vocational Education and Training 59 (4): 485501. doi:10.1080/13636820701650943.

Grip, Andries De. 2008. "Economic Perspectives of Workplace Learning." In The Learning Potential of the Workplace, ed. W.J. Nijhof and L.F.M. Nieuwenhuis, 15-29. Rotterdam: Sense Publishers.

Hoekstra, A., F. Korthagen, M. Brekelmans, D. Beijaard, and J. Imants. 2009. "Experienced Teachers' Informal Workplace Learning and Perceptions of Workplace Conditions." Journal of Workplace Learning 21 (4): 276-298. doi:10.1108/13665620910954193.

Hoyle, E., and P. D. John. 1995. Professional knowledge and professional practice. London: Cassell.

Hoyle, R.H. 1995. Structural Equation Modelling: Concepts, Issues, and Applications. Thousand Oaks, CA: Sage.

Hurley, Amy E., Terri A. Scandura, Chester A. Schriesheim, Michael T. Brannick, Anson Seers, Robert J. Vandenberg, and Larry J. Williams. 1997. "Exploratory and Confirmatory Factor Analysis: Guidelines, Issues, and Alternatives." Journal of Organizational Behavior 18 (6): 667-683. doi:10.1002/(SICI)10991379(199711)18:6<667::AID-JOB874>3.0.CO;2-T. 


\section{MEASURING TEACHERS' PROFESSIONAL DEVELOPMENT AT WORK}

Jurasaite-Harbison, Elena, and Lesley A. Rex. 2010. "School Cultures as Contexts for Informal Teacher Learning.” Teaching and Teacher Education 26 (2): 267-277. doi:10.1016/j.tate.2009.03.012.

Kaiser, Henry F. 1960. "The Application of Electronic Computers to Factor Analysis." Educational and Psychological Measurement 20 (1): 141-151.

Kelloway, E.K. 1995. “Structural Equation Modelling in Perspective.” Journal of Organizational Behavior 16: 215-224.

Kozma, R. 2003. "ICT and Educational Change: A Global Phenomenon.” In Technology, Innovation and Educational Change: A Global Perspective, ed. R. Kozma, 1-19. Eugene, OR: Information Society for Technology in Education (ISTE).

Kuiper-Rinsema, M.M.N. 2007. "Professional Development of Teachers in Vocational Education.” [Professionalisering van Docenten in Het VMBO.] Thesis. Twente University.

Kwakman, K. 2003. 'Factors Affecting Teachers' Participation in Professional Learning Activities." Teaching and Teacher Education 19 (2): 149-170. doi:10.1016/S0742051X(02)00101-4.

Law, N., W.J. Pelgrum, and T. Plomp, ed. 2008. Pedagogy and ICT Use in Schools around the World - Findings from the IEA SITES 2006 Study. Hong Kong: Springer.

Little, J.W. 1990. “The Persistence of Privacy: Autonomy and Initiative in Teachers' Professional Relations.” Teachers College Record 91: 509-536.

Livingston, K. 2012. “Approaches to professional development of teachers in Scotland: pedagogical innovation or financial necessity?" Educational Research 54 (2): 161-172. doi: dx.doi.org/10.1080/00131881.2012.680041.

Malloch, M., L. Cairns, K. Evans, and B. O'Connor, ed. 2011. The SAGE Handbook of Workplace Learning. Los Angeles, Ca: SAGE. 


\section{MEASURING TEACHERS' PROFESSIONAL DEVELOPMENT AT WORK}

Marcos, Juanjo Mena, Emilio Sanchez, and H. H. Tillema. 2011. "Promoting Teacher Reflection: What Is Said to Be Done.” Journal of Education for Teaching 37 (1): 21-36. doi:10.1080/02607476.2011.538269.

Marsh, H.W., J.R. Balla, and K.T. Hau. 1996. An Evaluation of Incremental Fit Indices: A Clarification of Mathematical and Empirical Properties. In Advanced Structural Equation Modeling: Issues and Techniques, ed. G.A. Marcoulides, and R. E. Schumacker, 315-353. Mahway, NJ: Erlbaum.

Michels, C.G.J., and J.M. Voeten. 1993. “Hoe Soms Is Vaak?” Tijdschrift Voor Onderwijsresearch 18 (1): 58-62.

Mulder, R.H., and A.D. Ellinger. 2013. "Perceptions of quality of feedback in organizations." European Journal of Training and Development 37 (1): 4-23.

Opfer, V. D., D.G. Pedder, and Z. Lavicza. 2011. “The role of teachers' orientation to learning in professional development and change: A national study of teachers in England.” Teaching and Teacher Education 27 (2): 443-453.

OECD. 2005. “Teachers Matter: Attracting, Developing and Retaining Effective Teachers.” Paris: Department for International Research and Cooperation National Institute for Educational Research. doi:10.1787/9789264022157-ja.

OECD. 2009. "Creating Effective Teaching and Learning Environments: First Results from TALIS 2008". Paris: OECD publishing.

Park, S., J.S. Oliver, T.S. Johnson, P. Graham, and N. K. Oppong. 2007. “Colleagues’ Roles in the Professional Development of Teachers: Results from a Research Study of National Board Certification." Teaching and Teacher Education 23 (4): 368-389. doi:10.1016/j.tate.2006.12.013. 


\section{MEASURING TEACHERS' PROFESSIONAL DEVELOPMENT AT WORK}

Park, Yoonhee, and R.L. Jacobs. 2011. "The Influence of Investment in Workplace Learning on Learning Outcomes and Organizational Performance." Human Resource Development Quarterly 22 (4): 368-389. doi:10.1002/hrdq.

Pelgrum, W.J., and Joke Voogt. 2009. "School and Teacher Factors Associated with

Frequency of ICT Use by Mathematics Teachers: Country Comparisons.” Education and Information Technologies 14: 293-308. doi:10.1007/s10639-009-9093-0.

Postholm, May Britt. 2012. "Teachers' professional development: a theoretical review". Educational Research 54 (4): 405-429. doi: dx.doi.org/10.1080/00131881.2012.734725.

Prilla, M., M. Degeling, and T. Herrmann. 2012, October. Collaborative reflection at work: supporting informal learning at a healthcare workplace. Proceedings of the 17th ACM international conference on supporting group work, 55-64. New York, NY, USA: ACM.

Ramani, S., and S.K. Krackov. 2012. "Twelve tips for giving feedback effectively in the clinical environment." Medical teacher 34 (10): 787-791.

Retallick, J. 1999. “Teachers’ Workplace Learning: Towards Legitimation and Accreditation." Teachers and Teaching: theory and practice 5 (1): 33-50.

Runhaar, P. 2008. "Promoting Teachers' Professional Development”. Doctoral dissertation, University of Twente, the Netherlands.

Schalk, M.J.D., B.I.J.M. Van der Heijden, A.H. De Lange, and M.J.P.M. Van Veldhoven. 2011. "Editoral, Long-Term Developments in Individual Work Behaviour: Patterns of Stability and Change." Journal of Occupational and Organizational Psychology 84: $215-227$.

Schön, D.A. 1983. The Reflective Practitioner: How Professionals Think in Action. Aldershot: Arena.

Stevens, J.P. 1992. Applied Multivariate Statistics for the Social Sciences. Hillsdale, NJ: Lawrence Erlbaum. 
Tynjälä, P. 2008. “Perspectives into Learning at the Workplace.” Educational Research Review 3: 130-154. doi:10.1016/j.edurev.2007.12.001.

Tynjälä, P. 2013. "Toward a Three-P- Model of Workplace Learning: A literature review." Vocations and Learning 6 (1): 11-36.

Vogels, R., and R. Bronneman-Helmers. 2006. Who Work in Education? In Search of the "characteristic Feature” of the Professional in Education [Wie Werken Er in Het Onderwijs? Op Zoek Naar Het "eigene” van de Onderwijs Professional]. Den Haag: SCP.

Voogt, Joke, and N.P. Roblin. 2012. “A Comparative Analysis of International Frameworks for 21st Century Competences: Implications for National Curriculum Policies.” Journal of Curriculum Studies 44 (3): 299-321. doi:10.1080/00220272.2012.668938.

Vygotsky, L.S. 1978. Mind in society: The development of higher psychological processes. Cambridge, Massachusetts: Harvard University Press.

Ward, L.W. 2005. "Putting Policy into Practice: Pedagogical Reform throughout ICT." Doctoral dissertation, University of Auckland. 


\section{Appendix 1. Removed Items}

Removed from original list (see for the original list Table 1):

- Item 5: Share ideas about education with colleagues. This item is already included in the item: 'Discussing ideas about educational improvement and innovation in my school with colleagues' (see item 21 in Table 2).

- Item 11: 'Study teaching manuals'. This item does not fit well in the category: 'keeping upto-date', because it is a normal lesson activity.

- Item 13: 'Help students to learn study skills'. The content of this item is included in the item: 'Trying out new teaching methods in class' (see item 6 in Table 2).

- Item 20: 'Talk about teaching problems with colleagues' and item 6: 'Support colleagues in teaching problems' are combined in 'Using peer coaching in case my colleagues and I experience teaching problems' (see item 18 in Table 2).

- Item 18: 'Use colleagues' materials in own lessons'. This item is removed, because it is already included in the item: 'Testing alternative teaching materials in class'. 


\section{MEASURING TEACHERS' PROFESSIONAL DEVELOPMENT AT WORK}

Table 1. The Original List of Kwakman (2003)

\begin{tabular}{ll}
\hline Item & \\
\hline 1. & Give opinion to school management \\
2. & Share ideas about pupil counseling \\
3. & Join a committee at the school \\
4. & Share ideas about educational improvement \\
5. & Share ideas about education with colleagues \\
6. & Support colleagues in teaching problems \\
7. & Study subject matter literature \\
8. & Read professional journals \\
9. & Ask pupils feedback \\
10. & Experiment with new teaching methods \\
11. & Study teaching manuals \\
12. & Adapt way of teaching to pupils' needs \\
13. & Help students to learn study skills \\
14. & Prepare lessons with colleagues \\
15. & Construct lesson materials \\
16. & Share way of teaching with colleagues \\
17. & Make agreements about way of teaching \\
18. & Use colleagues' materials in own lessons \\
19. & Collegial classroom observation* \\
20. & Talk about teaching problems with colleagues* \\
21. & Reflect individually on a lesson*
\end{tabular}

*Bold=removed items. Participants were asked to rate the items on frequency (using a 4-point rating scale; 1=hardly ever, 2=sometimes, $3=$ fairly often, and $4=0$ often) 


\section{MEASURING TEACHERS' PROFESSIONAL DEVELOPMENT AT WORK}

Table 2. The Survey List of Professional Learning Activities at Work

\begin{tabular}{|c|c|c|}
\hline \multirow{2}{*}{$\begin{array}{l}\text { Categories } \\
\text { Keeping up-to-date }\end{array}$} & \multicolumn{2}{|c|}{ Item } \\
\hline & & Studying subject matter literature $(7)^{*}$ \\
\hline & & Visiting educational sites on Internet (new item). \\
\hline & 3. & Reading educational/subject matter pedagogical literature (8). \\
\hline & 4. & $\begin{array}{l}\text { Participating in a one day conference or study day that centres around subject } \\
\text { matter pedagogy (new item). }\end{array}$ \\
\hline & 5. & $\begin{array}{l}\text { Participating in a training course that centres around subject matter pedagogy } \\
\text { (new item). }\end{array}$ \\
\hline \multirow[t]{5}{*}{ Experimenting } & 6. & Trying out new teaching methods in my lesson. (10) \\
\hline & & Trying out new applications of ICT in my lesson (new item). \\
\hline & 8. & Testing alternative teaching materials in class (15). \\
\hline & 9. & Applying and evaluating other forms of assessments (new item) \\
\hline & 10. & Inquiring new teaching methods in class (new item). \\
\hline \multirow[t]{5}{*}{ Reflecting and asking for feedback } & 11. & Asking pupils for feedback on the way I teach (9). \\
\hline & 12. & Reflecting on the different educational applications of ICT (new item). \\
\hline & 13. & Reflecting on my strong and weak points (21). \\
\hline & 14. & Inviting colleagues to attend my lesson (19). \\
\hline & 15. & Adapting my teaching methods in response to pupils' reactions (12). \\
\hline \multirow{5}{*}{$\begin{array}{l}\text { Collaborating with colleagues with the aim of improv- } \\
\text { ing lessons }\end{array}$} & 16. & Discussing the teaching approaches I use in class with colleagues (16). \\
\hline & 17. & $\begin{array}{l}\text { Discussing lessons with colleagues in an Electronic Learning Environment (ELO) } \\
\text { (new item). }\end{array}$ \\
\hline & 18. & $\begin{array}{l}\text { Using peer coaching in case my colleagues and I experience teaching problems } \\
\text { (item } 20 \text { and 6). }\end{array}$ \\
\hline & 19. & Preparing lessons with colleagues (14). \\
\hline & 20. & Making agreements with colleagues about the pedagogical practices (17). \\
\hline \multirow[t]{5}{*}{$\begin{array}{l}\text { Collaborating with colleagues with the aim of improv- } \\
\text { ing school development }\end{array}$} & 21. & $\begin{array}{l}\text { Discussing ideas about educational improvement and innovation in my school } \\
\text { with colleagues (4). }\end{array}$ \\
\hline & 22. & $\begin{array}{l}\text { Discussing school organisational matters with colleagues in an Electronic Learn- } \\
\text { ing Environment (ELO) (new item). }\end{array}$ \\
\hline & 23. & Thinking about the design and method of pupil counselling with colleagues (2). \\
\hline & 24. & Assembling a school working group or committee with colleagues (3). \\
\hline & 25. & $\begin{array}{l}\text { Giving an opinion together with colleagues about school organisational matters } \\
\text { to the school management (1). }\end{array}$ \\
\hline
\end{tabular}

*If an item is based on an original item of Kwakman's survey, then the number of that original item of Kwakman's survey is displayed between brackets. Participants were asked to rate using a 4-point rating scale; $1=$ hardly ever, 2=sometimes, 3=fairly often, and 4=often. 
MEASURING TEACHERS' PROFESSIONAL DEVELOPMENT AT WORK

Table 3. Sample Characteristics

\begin{tabular}{lcc}
\hline & Primary teachers & Secondary teachers \\
& $n=118$ & $n=574$ \\
& Sample & Sample \\
$\%$ & $\%$ \\
\hline Gender & & \\
Men & 13.0 & 52.8 \\
Women & 87.0 & 47.2 \\
Education & & \\
Low & 0.0 & 4.2 \\
Middle & 4.2 & 0.9 \\
Bachelor & 90.7 & 73.2 \\
Master & 5.1 & 21.8 \\
Age & & \\
$<21$ & 0.8 & 0.2 \\
$21-25$ & 11.9 & 10.5 \\
$26-30$ & 9.3 & 9.2 \\
$31-35$ & 6.8 & 2.8 \\
$36-40$ & 16.1 & 7.7 \\
$41-45$ & 16.1 & 11.0 \\
$46-50$ & 16.9 & 13.2 \\
$51-55$ & 13.6 & 21.8 \\
$56-60$ & 5.9 & 18.1 \\
$61-65$ & 2.5 & 5.6 \\
$>65$ & 0.0 & 0.0 \\
\hline & &
\end{tabular}




\section{MEASURING TEACHERS' PROFESSIONAL DEVELOPMENT AT WORK}

Table 4. Concluding List of Learning Activities after Final Exploratory Factor Analysis of Sub set $1 ; n=346$

\begin{tabular}{|c|c|c|c|c|c|c|}
\hline & Comp & & & & & \\
\hline Item & 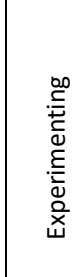 & 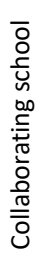 & 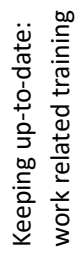 & 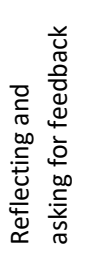 & 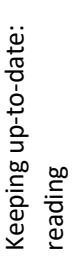 & 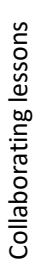 \\
\hline
\end{tabular}

i8 Testing alternative teaching materials in class.

.77

i7. Trying out new applications of ICT in my lesson.

.76

i9. Applying and evaluating other forms of assessments.

i10. Inquiring new teaching methods in class.

i6. Trying out new teaching methods in my lesson.

i25. Giving an opinion together with colleagues about school organisational matters to the school management.

i24. Assembling a school working group or committee with colleagues.

i23. Thinking about the design and method of pupil counseling with colleagues.

i21. Discussing ideas about educational improvement and innovation in my school with colleagues.

i5. Participating in a training course that centres around subject matter pedagogy.

i4. Participating in a one day conference or study day that centres around subject matter pedagogy.

i13. Reflecting on my strong and weak points.

i15. Adapting my teaching methods in response to pupils' reactions.

i11. Asking pupils for feedback on the way I teach.

i14. Inviting colleagues to attend my lesson.

i1. Studying subject matter literature.

i3. Reading educational/subject matter pedagogical literature.

i2. Visiting educational sites on the Internet.

i19. Preparing lessons with colleagues.

i20. Making agreements with colleagues about the pedagogical practices.

i16. Discussing the teaching approaches I use in class with colleagues.

\section{.74}

.70

.67

.84

.75

.54

.89

.84

.76

.69

.57

.44

- 82

$82-$

.71

$-.81$

$-.79$

$-.45$

Eigenvalue

5.77

2.04

1.65

1.30

$1.09 \quad 1.05$ 
MEASURING TEACHERS' PROFESSIONAL DEVELOPMENT AT WORK

Table 5. Means, Standard Deviations, and Reliabilities of TPD@Work Subscales

\begin{tabular}{lcc}
\hline Subscales & Mean (SD) & Cronbach's $\alpha$ \\
\hline Experimenting & $2.32(.63)$ & .80 \\
Collaborating with colleagues with the aim of improving school & $2.50(.67)$ & .73 \\
development & & \\
Keeping up-to-date: participation in training related to work & $1.90(.73)$ & .72 \\
Reflecting and asking for feedback & $2.37(.57)$ & .67 \\
Keeping up-to-date: reading & $2.72(.70)$ & .73 \\
Collaborating with colleagues with the aim of improving lessons & $2.42(.65)$ & .67 \\
\hline
\end{tabular}




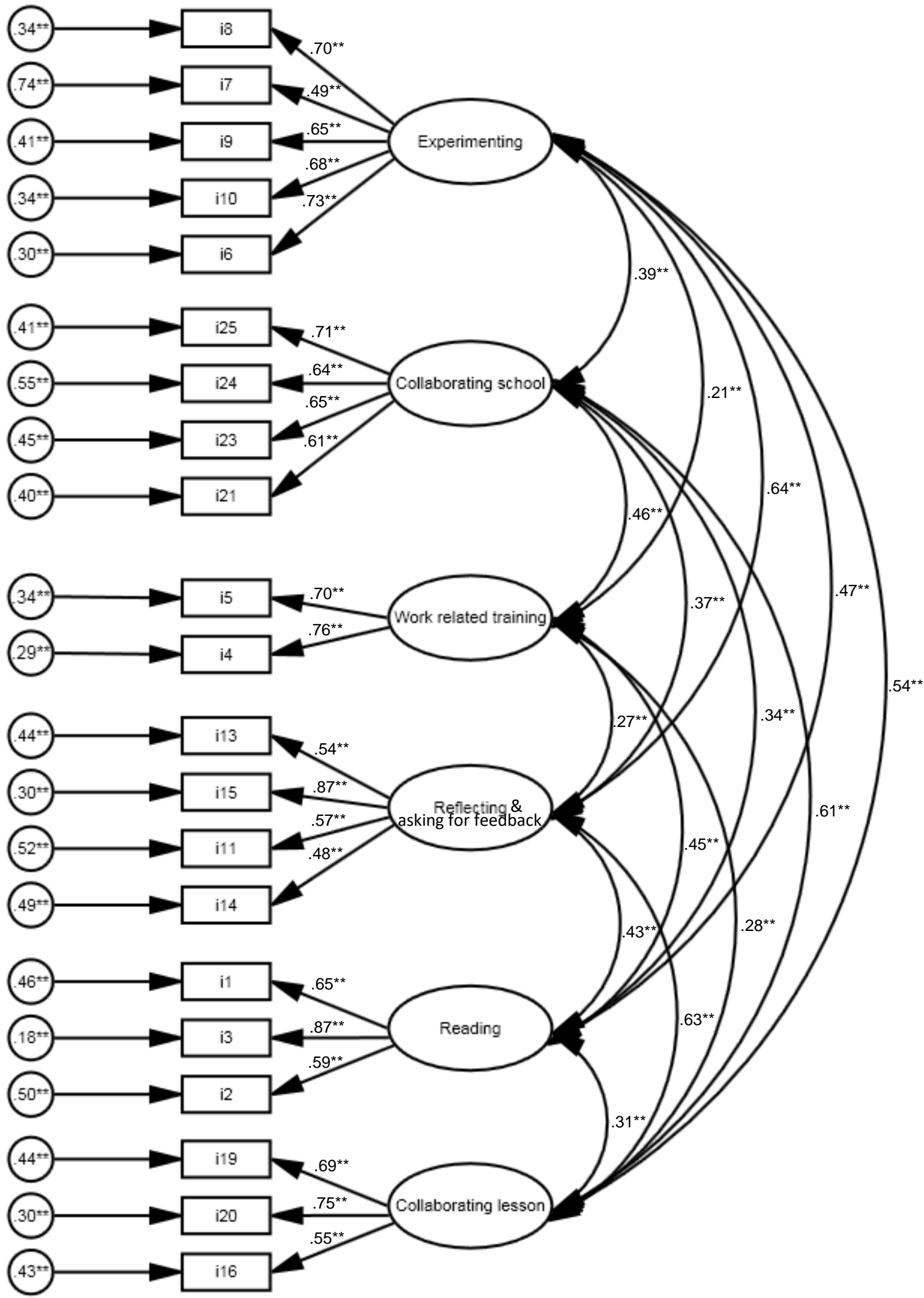

Figure 1. Estimated factor inter-correlations, factor loadings, and error variances of the CFA. 